\title{
宇宙半導体レーザ溶接の宇宙適用を目指した光学部品の金属蒸着防止技術*1 Preventing Technique of Metal Deposition on Optical Devices in Space Diode Laser Welding for Space Applications
}

\author{
吹田 義 - ${ }^{* 2} \cdot$ 田 中 健 司 $^{* 2} \cdot$ 大谷 雅 人 $^{* 2} \cdot$ 正箱 信一郎*2 \\ Yoshikazu Suita, Kenji Tanaka, Masato Ohtani, Shinichiro Shobako, \\ 寺 嶋昇*2.平 岡 延 章*2 \\ Noboru Terajima and Nobuaki HiRAOKA
}

\begin{abstract}
Key Words : Process \& Production, Space Diode Laser Welding, Metal Deposition, Optical Device, Stainless Steel
\end{abstract}
\begin{abstract}
In future space developments, the welding in space may be required for the repairs of the ISS and the constructions of lunar base and space structures. The authors have studied the space Gas Hollow Tungsten Arc (GHTA) welding process since 1993. This paper describes the results for space applying the space Diode Laser (DL) welding process which the authors proposed in 2002. It is necessary to prevent the metal deposition on optical devices in order to utilize the space DL welding process in space. The authors studied the preventing technique of metal deposition which covered optical devices with the nozzle and blew the shielding gas out from nozzle outlet. The metal deposition can be reduced by supplying the nozzle with inert gas and blowing the gas out from nozzle outlet. The shielding gas argon perfectly prevents the metal deposition on optical devices when argon pressurizes the nozzle to over $19.9 \mathrm{~Pa}$ and spouts out from the nozzle outlet.
\end{abstract}

\section{1. 緒論}

日本時間 2009 年 7 月 19 日 11 時 23 分，国際宇宙ステー ション ISS に長期滞在する若田光一宇宙飛行士は, ロボット アームを巧みに操作してスペース・シャトル「エンデバー」 で打ち上げられた船外実験施設を日本実験棟「きぼう」の 船内実験室に取り付けた . 構想から 27 年, 日本の悲願で あった宇宙実験施設「きぼう」が完成した。

ISS の運用期間は, 約 10 年の長期間に亘るのでスペー ス・デブリや隕石の衝突による損傷の修理や改造に溶接技 術が必要になることも予想される . また, 宇宙空間での宇 宙構造物の建設や月面基地建設には宇宙溶接技術の適用が 期待されている. 宇宙溶接技術は，1960 年頃から旧ソビ エト連邦, 米国の電子ビーム溶接 ${ }^{1 \sim 3)}$ の研究に始まり，我 が国でも 1990 年代に研究 ${ }^{4)}$ が行われた . NASA はISS の 補修に溶接技術が適用できることを確認するために，パト ン電気溶接研究所か開発した電子ビーム溶接装置をスペー ス・シャトルに搭載して，1997 年 10 月に宇宙空間で溶接 実験を行う計画をした ・しかし，スペース・シャトルのス ケジュールや宇宙飛行士の安全確保に問題が発生して溶接 実験を無期延期5)にした。

一方, 宇宙適用を目指したアーク溶接 6 ๑) やレーザ溶接の

*1 (C) 2010 日本航空宇宙学会

平成 17 年 11 月 9 日, 第 49 回宇宙科学技術連合講演会において 発表. 平成 21 年 9 月 2 日原稿受付

*2 高松工業高等専門学校制御情報工学科
研究も行われた . 1991 年に米国でNd-YAGレーザ溶接 ${ }^{10)}$ の研究が行われたが, 大型・大重量で発振効率が低いなど の問題があった . 近年, 半導体レーザ (Diode Laser , 以 下は DL と記述) 装置, ファイバーレーザ装置の高出力化 が目覚しく進展した .これらのレーザ装置は, 高発振効率, 小型・軽量などの特長を持つために宇宙空間での宇宙構造 物の建造・修理などに適用できる可能性を持っている.著 者らは, 兴の特長に注目して宇宙 DL 溶接技術 ${ }^{11,12)}$ を提案 した .しかし , 低圧環境のレーザ溶接では, 溶接中の金属 蒸着現象 ${ }^{13)}$ によって光学部品の透過率低下, 劣化や破損な どの諸問題が発生することも指摘した .

本研究では, 弚のような金属蒸着に起因する光学部品の 諸問題を解決する方法を検討した .フォーカッシング・ユ ニット，レーザ導入石英密などレーザ射出部の光学部品を 保護するために設置した石英板の金属蒸着を抑制・防止する 方法を検討した、研究の結果，レーザ射出部にノズルを設 置し，極少量のシールドガスをノズルに供給してノズル口 から噴出させる方法で石英板の金属蒸着を防止できること を明らかにした . この光学部品の金属蒸着防止技術によっ て, 著者らが提案している宇宙 DL 溶接技術が宇宙で適用 できる可能性を示すことができたので報告する．

\section{2. 実験装置および実験方法}

2.1 実験装置 実験に使用した高真空 DL 溶接実験シ ステムを第 1 図に示す. 実験システムは, 真空装置 (真空 チャンバ容積 $0.17 \mathrm{~m}^{3}$, 到達圧力 $\left.6 \times 10^{-6} \mathrm{~Pa}\right), 2.5 \mathrm{~kW}$ 連 


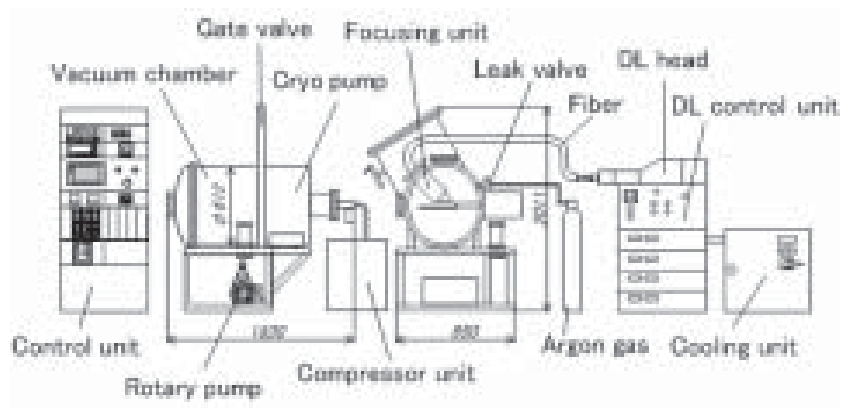

第 1 図＼cjkstart高真空半導体レーザ溶接実験システム

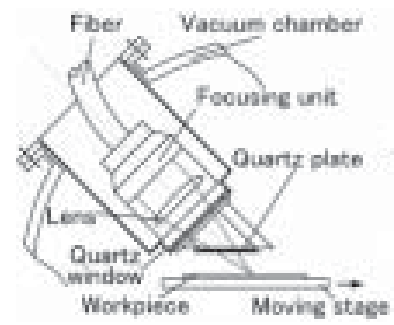

(a)ノズル無ユニット

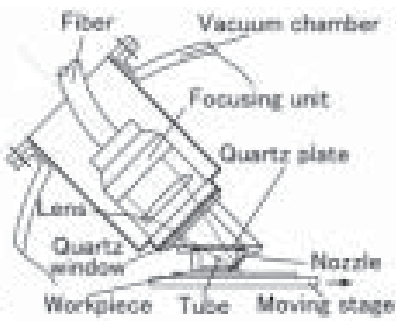

(b)ノズル付ユニット

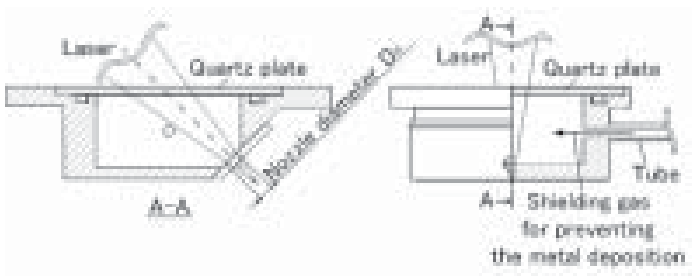

(c)ノズル

第 2 図 フォーカッシング・ユニットとノズル

続発振ダイレクト・ダイオードレーザ装置と制御装置で構 成される . 真空ポンプには, ロータリポンプ $\left(\mathrm{N}_{2}\right.$ 排気速度 $0.65 \mathrm{~m}^{3} / \mathrm{min}$ ) とクライオポンプ ( $\mathrm{Ar}$ 排気速度 $8.4 \mathrm{~m}^{3} / \mathrm{s}$ ) を使用した . DL ヘッドからコア径 $1.5 \mathrm{~mm}$ の光ファイバで 約 $2 \mathrm{~kW}$ ，混合波長 $(808,940) \pm 10 \mathrm{~nm}$ のレーザ光をフォー カッシング・ユニット (Focusing unit, 焦点距離 $120 \mathrm{~mm}$ ) に伝送した .フォーカッシング・ユニットは , 真空仕樣で ないために第 2 図 (a) に示すように真空チャンバ外部に設 置した .レーザ光はレーザ導入石英空 (Quarts window， 直径 $70 \mathrm{~mm}$, 板厚 $8 \mathrm{~mm}$ ) から真空チャンバ内部に導入さ れ，フォーカッシング・ユニット先端部に設置した石英板 (Quartz plate, 直径 $70 \mathrm{~mm}$, 板厚 $2.2 \mathrm{~mm}$ ) を通して移動 ステージ (Moving stage) 上の供試材に照射された。石英 板は, 金属蒸着による光学部品 (フォーカッシング・ユニッ 卜，レーザ導入石英密など）の透過率低下，劣化・損傷か ら保護する目的で設置した . 本研究では, この石英板にノ ズルを装着する方法で光学部品の金属蒸着防止技術を検討 した . 第 2 図 (a) は，過去の実験で使用したノズルの無い フォーカッシング・ユニット (以下 , ノズル無ユニットと 記述) と石英板，移動ステージ，供試材を示す.第 2 図 (b) は本実験で使用した石英板を被うノズルを装着したフォー カッシング・ユニット (以下，ノズル付ユニットと記述)，
第 2 図 (c) はノズルの詳細図である .ノズルの右下先端部 にレーザ光を通すノズル口径 $D_{\mathrm{n}}$ の孔を設け , ノズル口径 がノズル内に進入する蒸発金属を遮蔽する効果，またノズ ルからシールドガスを噴出させて石英板の金属蒸着を抑制・ 防止する効果を調査した .

2.2 供試材と実験方法 購入状態で表面を脱脂した SUS304 ステンレス鋼板（板厚 $3 \mathrm{~mm}$ ，板幅 $90 \mathrm{~mm}$ ，長さ $80 \mathrm{~mm}$ ）を供試材に使用した . 真空チャンバ内圧力は溶接 部から $0.3 \mathrm{~m}$ に設置した改良ベアード・アルパート型電離真 空計で測定した . 移動ステージに供試材を固定した後, 真 空チャンバ内を $10^{-5} \mathrm{~Pa}$ まで排気して溶接した . 溶接法は 供試材表面を溶融させるメルトラン溶接とした . 溶接速度 $2 \mathrm{~mm} / \mathrm{s}$, 溶接時間約 30 秒で板幅中央部を長さ方向に溶接 長約 $60 \mathrm{~mm}$ の溶接を行った .レーザ照射条件は, 照射角 $45^{\circ}$ ，供試材表面が焦点となるジャストフォーカス（レーザ 光照射寸法は，供試材表面で長径約 $4 \mathrm{~mm}$, 短径 $3 \mathrm{~mm}$ の 楕円) で,レーザパワー実測值は $1.7 \mathrm{~kW}$ である .ノズルか らシールドガスを噴出させる溶接実験では, 供試材を固定 した後に真空チャンバ内を $10^{-5} \mathrm{~Pa}$ に排気後，所定流量の シールドガスをノズルロから噴出させて真空チャンバ内圧 力が定常圧力になった状態で溶接を開始した . 真空チャン バ内圧力は, 金属蒸気やシールドガスの種類に応じた相対 感度係数で修正した圧力を，またシールドガス流量は STP 標準状態流量 $\left(0^{\circ} \mathrm{C}, 1 \mathrm{~atm}\right)$ で表示した。石英板のレーザ 光が透過する部分 (以下, レーザ光透過部と記述) の平均透 過率は, 分光光度計を使用して測定波長 808〜 $940 \mathrm{~nm}$ の範 囲で計測した透過率の平均値とした . 金属蒸着によるレー ザ光透過部の透過率低下量は, 溶接前後の平均透過率の差 として求めた . 溶接金属の寸法は, 溶接開始点から $40 \mathrm{~mm}$ の位置の断面マクロ組織を観察して測定した .

\section{3. 実験結果と考察}

3.1 ノズルによる金属蒸気の遮蔽効果の検討 ノズル が金属蒸気を遮蔽する効果を調べるために，第 2 図 (a)の ノズル無ユニットを使用した溶接実験とシールドガスを用 いないで第 2 図 (b)のノズル付ユニットを使用してノズル 口径 $D_{\mathrm{n}}$ を $8,10,12 \mathrm{~mm}$ に変化させた溶接実験を行った。 溶接を開始すると溶融池から金属蒸気が発生し, 真空チャ ンバ内圧力は急上昇する．しかし，圧力は発生する金属蒸 気量と真空ポンプの排気能力で決まる定常圧力に収束する. 今回の溶接条件では，溶接開始前 $10^{-5} \mathrm{~Pa}$ であった圧力は， 溶接開始から約 3 秒後に定常圧力 $1.7 \times 10^{-3} \mathrm{~Pa}$ にまで上 昇し, 溶接終了まで変化しなかった .

低圧環境では金属が溶融すると金属蒸気が発生し，周囲 物体の表面に金属蒸着膜が付着する金属蒸着現象が発生す る. 光学部品の表面に付着した金属蒸着膜は, レーザ光を 吸収して発熱するので光学部品を損傷させる. 弚のために， 光学部品の金属蒸着防止技術の確立が宇宙レーザ溶接技術 の実用化にあたって大きな課題になっている.第 1 表は，ノ ズル口径 $D_{\mathrm{n}}$ と溶接後の石英板の金属蒸着状況および溶融 部寸法 (溶接金属寸法) の関係である.表中には , ノズル無 
第 1 表 ノズル口径と石英板の金属蒸着状況，溶接金属寸法の関係
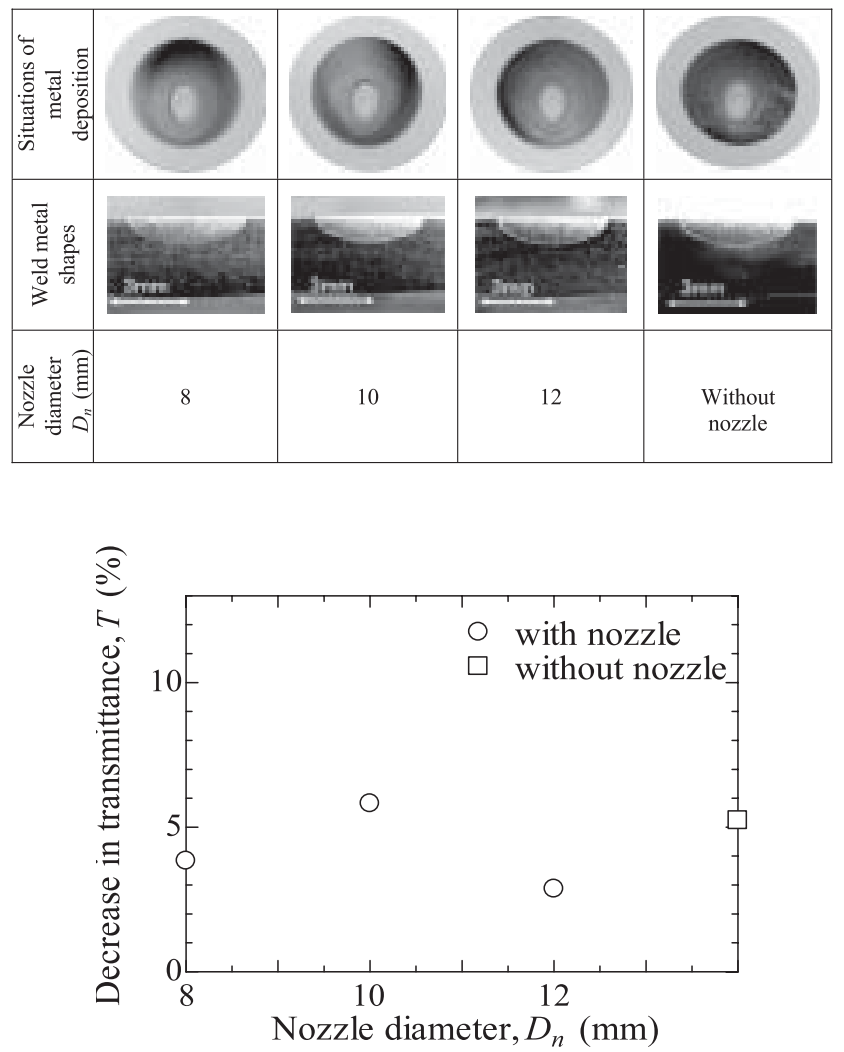

第 3 図 ノズル口径と透過率低下量の関係

ユニットを使用した結果も示している.第 1 表の実験結果 は , ノズルの有無やノズル口径 $D_{\mathrm{n}}$ は金属蒸着状況と溶接 金属寸法に影響を与えないことを示している．石英板中央 付近のほぼ透明に見える楕円部分がレーザ光透過部で，光 こでは金属蒸着膜が再蒸発している.レーザ光透過部の外 側は，レーザ光吸収による発熱が少ないので再蒸発も少な く, 銀色の金属蒸着膜が残留している. 溶接金属は楕円状 で, 溶接金属の幅はレーザ照射寸法の短径 $3 \mathrm{~mm}$ よりもわ ずかに広い約 $3.8 \mathrm{~mm}$ ，溶込み深さは約 $1.0 \mathrm{~mm}$ であった .

未使用石英板の平均透過率 (測定波長 808 940 nm) は $92 \%$ である.レーザ光透過部は金属蒸着現象とレーザ光を 吸収した金属蒸着膜が再蒸発する現象が繰り返されて劣化 する．光のために，透過率の低下が起こり，部分的な溶融 やき裂が発生することがある. 第 3 図はノズル口径とレー ザ光透過部の透過率低下量の関係である. 透過率低下量は ノズル口径に関係なく約 3〜6\%の範囲でほぼ同じ值を示し， ノズル無ユニットを使用した結果 (口印) とほぼ同じ值で あった 。

著者らは, 第 2 図 (a)のノズル無ユニットを使用したレー ザ光の斜め照射溶接実験によって, 溶融池から発生する金 属蒸気の分子密度分布は余弦法則 ${ }^{13)}$ に従い, 球状分布に なることを示した．弚のような金属蒸発特性に注目して， 本研究では $45^{\circ}$ 傾けたノズルを設置して金属蒸気の大部分 を遮蔽する方法を検討した．しかしながら，第 1 表と第 3 図の実験結果は, 蒸発した金属蒸気の一部がノズル内に侵
第 2 表 シールドガスの種類が石英板の金属蒸着状況と 溶接金属寸法に及ぼす影響

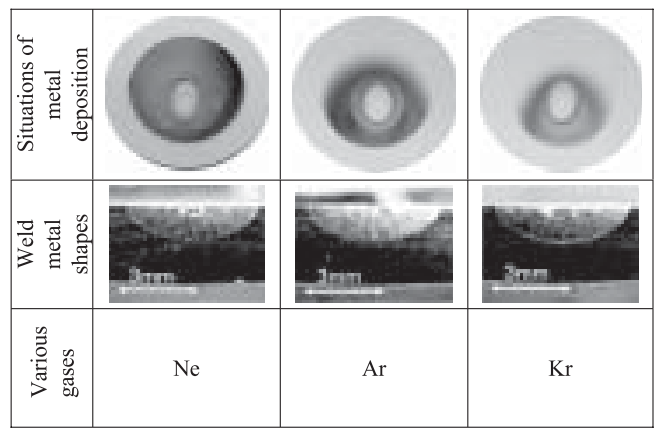

入しただけでも石英板の金属蒸着を充分に抑制できないこ とを示している . 兴の主な理由は, 真空チャンバ内圧力が $1.7 \times 10^{-3} \mathrm{~Pa}$ の低圧であるために，鉄気体分子の平均自由 行程が長く，鉄気体分子が石英板に到達する確率が高いた めと考えられる (付録 1 参照) .

3.2 シールドガスの種類が石英板の金属蒸着状況と溶 接金属寸法に及ぼす影響 第 2 図 (b)のノズル付ユニット (ノズル口径 $8 \mathrm{~mm}$ ) を使用して, シールドガスの供給と 種類が石英板の金属蒸着を抑制する効果を調べた . 少流量 $0.17 \mathrm{ml} / \mathrm{s}$ の不活性ガス $\mathrm{Ne}, \mathrm{Ar}$ および $\mathrm{Kr}$ をシールドガス としてノズルに供給し, ノズル口から噴出させながら溶接 した . ガスの種類によって真空ポンプの排気能力が異なる ために, 真空チャンバ内の定常圧力は $\mathrm{Ne}, \mathrm{Ar}, \mathrm{Kr}$ で, 光

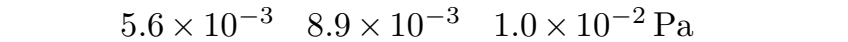
30 秒間の溶接中, 弚れらの定常圧力は変化しなかった .

第 2 表はシールドガスの種類が溶接後の石英板の金属蒸 着状況と溶接金属寸法に及ぼす影響である．Neの場合は， レーザ光透過部外側の金属蒸着はわずかしか抑制できてい ない．しかし， $\mathrm{Ar} ， \mathrm{Kr}$ では金属蒸着の抑制か確認できた 同じガス流量であれば，分子量の大きいガスほど金属蒸着 を抑制する効果が大きいことがわかる．図には示していな いが , レーザ光透過部の透過率低下量は約 2〜 4\%の範囲で， シールドガスを噴出させない場合（約 3 6\%) よりもわず かながら少なくなった . ガスの種類による透過率低下量の 違いは確認できなかった．また，溶融部寸法 (溶接金属寸 法) にもガスの種類による違いは確認できない，溶接金属 の幅は約 $5.3 \mathrm{~mm}$, 溶込み深さは約 $1.5 \mathrm{~mm}$ で, シールド ガスを使用しなかった第 1 表の溶接金属寸法よりも幅は約 $1.5 \mathrm{~mm}$, 深さは $0.5 \mathrm{~mm}$ 大きい .この結果は, シールドガ スをノズルに供給し , ノズル口から噴出させることで供試 材表面に照射されたレーザパワーが大きくなったことを裏 付けている.供試材に照射されたレレーザパワーが大きくなっ た理由は, シールドガスの供給でノズル内圧力が上昇した ためである .ノズル内圧力の上昇て鉄気体分子の平均自由 行程が小さくなて石英板への到達確率が低下して金属蒸 着を抑制できたためと考えられる (付録 2 参照) . 少流量 $0.17 \mathrm{ml} / \mathrm{s}$ の不活性ガス $\mathrm{Ne}, \mathrm{Ar}$ および $\mathrm{Kr}$ を供給した実験 では, 透過率低下量と溶接金属寸法にシールドガスの種類 
第 3 表 $\mathrm{Ar}$ ガス流量が石英板の金属蒸着状況と溶接金属寸法に及ぼす影響

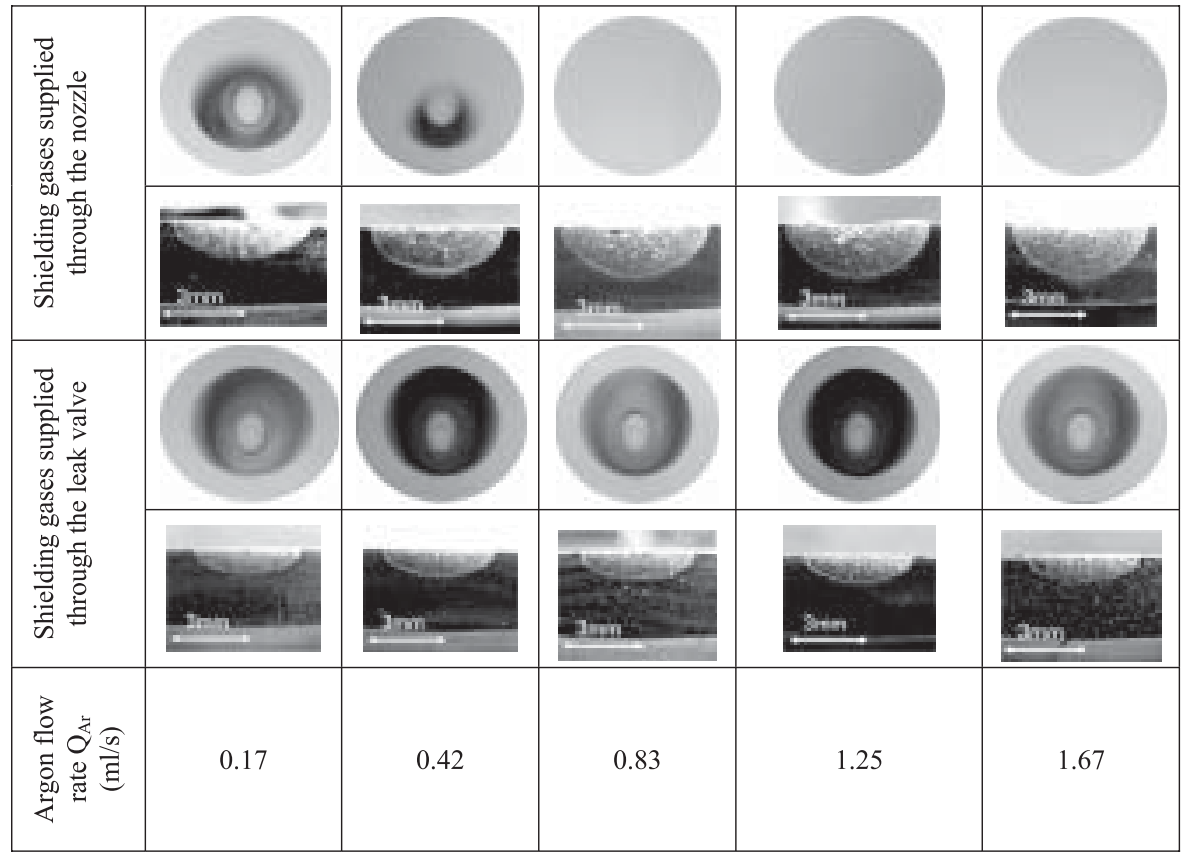

の影響が確認できなかった原因は, ガス流量が少ないため にレーザ光透過部の金属蒸着の抑制が不充分なためと推察 される .

$3.3 \mathrm{Ar}$ シールドガス流量が石英板の金属蒸着状況と溶 接金属寸法に及ぼす影響 $\mathrm{Ar}$ シールドガス流量が石英板の 金属蒸着を抑制・防止する効果と溶接金属寸法に及ぼす影響 を調査するために, ノズル口径 $8 \mathrm{~mm}$ からガス流量 0.17〜 $1.67 \mathrm{ml} / \mathrm{s}$ の $\mathrm{Ar}$ を噴出させながら溶接する実験を行った . 溶接開始前の真空チャンバ内の定常圧力は, $\mathrm{Ar}$ 流量にほぼ 比例して $8.9 \times 10^{-3} \sim 5.7 \times 10^{-2} \mathrm{~Pa}$ の範囲で高くなった . これらの定常圧力は, 溶接中は変化しなかった . 真空チャ ンバ内の圧力が高くなると金属蒸着が起き難くなることが 知られている. 弚こで, ノズルに Ar を供給し，ノズル口 から噴出させた場合の金属蒸着の抑制・防止効果を調べる ために，第 1 図に示す溶接部から約 $0.3 \mathrm{~m}$ 離れたリークバ ルブから $\mathrm{Ar}$ を流入させて , ノズルロから $\mathrm{Ar}$ を噴出させた 場合と同じ定常圧力でも溶接実験を行った .

第 3 表は Ar 流量と石英板の金属蒸着状況，溶接金属寸法 の関係である.上側の図がノズル口径 $8 \mathrm{~mm}$ から $\mathrm{Ar}$ を噴 出させた結果，下側の図がリークバルブから Ar を流入させ た結果である .ノズルロから Ar を噴出させた場合は, ガス 流量の増加とともに金属蒸着が少なくなり，流量 $0.83 \mathrm{ml} / \mathrm{s}$ 以上では金属蒸着が防止できた .一方, リークバルブから $\mathrm{Ar}$ を流入させた溶接では, ガス流量 $0.83 \mathrm{ml} / \mathrm{s}$ 以上でも石 英板に金属蒸着膜が付着した . この差異が , ノズル口から $\mathrm{Ar}$ を噴出させた効果である . ノズル口から $\mathrm{Ar}$ を噴出させ た場合は，ガス流量が多くなると溶接金属の幅，溶込み深 さがわずかに大きくなるが, 流量 $0.83 \mathrm{ml} / \mathrm{s}$ 以上では同じ 寸法になった .一方, リークバルブから Ar を流入させた 場合は, どのガス流量でもノズル口から $\mathrm{Ar}$ を噴出させた

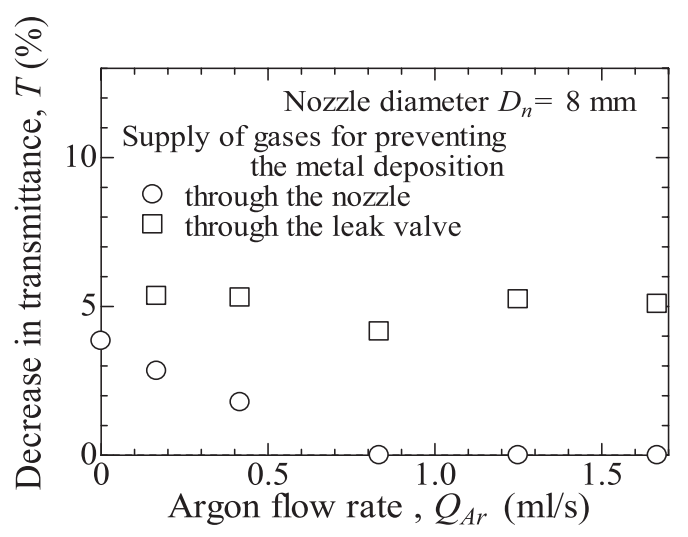

第 4 図 Ar ガス流量と透過率低下量の関係

場合に比べて溶接金属の幅，溶込み深さは小さく，供試材 に照射されたレーザパワーが小さいことを示している．

第 4 图は $\mathrm{Ar}$ 流量がレーザ光透過部の透過率低下量に及 ぼす影響である。印のノズル口径 $8 \mathrm{~mm}$ から $\mathrm{Ar}$ を噴出 させた結果は, ガス流量か増加すると透過率低下量は減少 し, 流量 $0.83 \mathrm{ml} / \mathrm{s}$ 以上では透過率低下量はゼロになった。 一方, 聊のリークバルブから Ar を流入させた場合は, ど のガス流量でも透過率低下量は 4 6\%の範囲でほぼ同じ値 を示し，第 3 図のシールドガスを用いない場合の透過率低 下量 $3 \sim 6 \%$ とほぼ同じであった .これらの結果から , ガス 流量 $0.83 \mathrm{ml} / \mathrm{s}$ 以上の $\mathrm{Ar}$ をノズルに供給して , ノズル口か ら噴出させると石英板の金属蒸着が抑制・防止できること がわかった . Ar 流量 $0.83 \mathrm{ml} / \mathrm{s}$ をノズルに供給してノズル 口径 $8 \mathrm{~mm}$ から噴出させた場合のノズル内圧力を付録 2 の 考え方で概算すると $16.9 \mathrm{~Pa}$ になる . したがって, 今回の

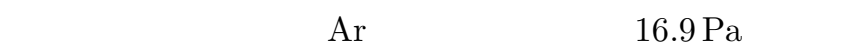




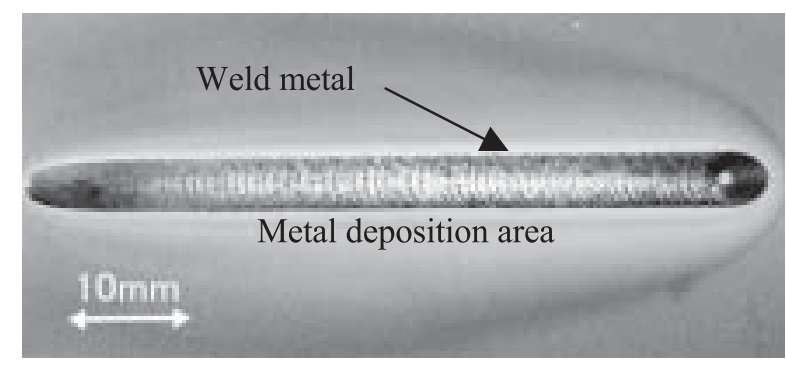

第 5 図 溶接金属周辺の金属蒸着状況

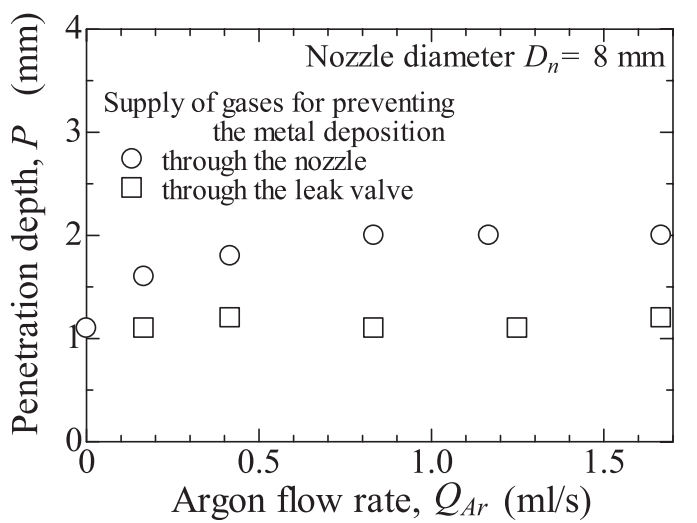

第 6 图 $\mathrm{Ar}$ ガス流量と溶込み深さの関係

高くすれば石英板の金属蒸着を防止でき，レーザ光透過部 の透過率の低下を防ぐことができることがわかった（付録 3 参照).

第 5 図は $\mathrm{Ar}$ 流量 $0.83 \mathrm{ml} / \mathrm{s}$ で溶接された供試材の表面 状況である . 溶接金属と光の周辺に金属蒸気が付着した金 属蒸着膜 (溶接金属周辺の白く变色した領域) か観察され た . 溶接中の真空チャンバ内の定常圧力 $3.0 \times 10^{-2} \mathrm{~Pa}$ と ノズル内圧力 $16.9 \mathrm{~Pa}$ の圧力比は約 $1.8 \times 10^{-3}$ で小さな值 である . 兴のために流速係数が大きく，ノズル口から噴出 する $\mathrm{Ar}$ の流速は音速に近くなる . 兴の Ar 噴流が金属蒸気 を供試材表面に押し戻し，金属蒸気膜が付着したと考えら れる。

第 6 図は Ar 流量と溶接金属の溶込み深さの関係である . ○印のノズル口から Ar を噴出させた場合は, 溶込み深さは ガス流量の増加とともに深くなり，流量 $0.83 \mathrm{ml} / \mathrm{s}$ 以上で は, 今回のレーザ溶接条件での最大の溶込み深さ約 $2 \mathrm{~mm}$ に達した . 弚れに対して, 叨のリークバルブから流入さ せた場合は，溶込み深さは $\mathrm{Ar}$ 流量に関係なく約 $1 \mathrm{~mm}$ で， 第 3 図のシールドガスを流出させない場合とほぼ同じ溶込 み深さであった .これらの結果は, 第 4 図の Ar 流量がレー ザ透過部の透過率低下量に及ぼす結果と同じ傾向を示して いる。

Ar シールドガスをノズルに供給し，ノズル内圧力を $16.9 \mathrm{~Pa}$ 以上にすることで石英板の金属蒸着を防止できる ことを示した . また，総計 1 時間以上の溶接を行っても石 英板のレーザ光透過部には, 部分的な溶融やき裂などの損 傷が発生しないことを確認した，本研究で提案する光学部
品をノズルで被い，シールドガスを使用する金属蒸着防止 技術は，宇宙 DL 溶接技術の宇宙適用を可能にするものと 考えられる。

\section{4. 結論}

宇宙 DL 溶接技術を実用化するには, 光学部品の金属蒸 着を防止する技術を確立する必要がある . フォーカッシン グ・ユニット先端部に設置した石英板の金属蒸着を抑制・ 防止するために，石英板をノズルで被い金属蒸気を遮蔽す る方法 , ノズルにシールドガスを供給してノズルロから噴 出させる方法について検討した . SUS304 ステンレス鋼を 供試材にした低圧中での半導体レーザ溶接実験で，次のこ とを明らかにできた .

1) シールドガスを用いないで, 溶融池近傍に $45^{\circ}$ 傾け た口径 $D_{\mathrm{n}}=8 \sim 12 \mathrm{~mm}$ のノズルを設置しただけでは，石 英板の金属蒸着は充分に抑制できない．

2 ） シールドガスを用いない場合は，石英板レーザ光透過 部の透過率低下量はノズルの有無やノズル口径に関係なく 約 3〜 6\%範囲であった .

3) ノズルにシールドガスとして $\mathrm{Ne}, \mathrm{Ar}, \mathrm{Kr}$ を供給し， ノズル口から噴出させると石英板の金属蒸着を抑制でき， レーザ光透過部の透過率低下を低減できる．

4) 分子量の大きいシールドガスは, レーザ光透過部外側 の金属蒸着を抑制する効果が大きい.

5) Ar シールドガスの場合は , ノズル内の圧力を $16.9 \mathrm{~Pa}$ (ノズル口径 $8 \mathrm{~mm}$ の場合は, $\mathrm{Ar}$ シールドガス流量 $0.83 \mathrm{ml} / \mathrm{s})$ よりも高くすると石英板の金属蒸着を防止で き,レーザ光透過部の透過率低下量をゼロにすることがで きる .

\section{参 考 文 献}

1) Paton, B. E.: Welding in Space, Welding Engineer, 57 (1972), pp. 25-29.

2) Dzhanibekov, V. A., Zagrebelny, A. A., Gavrish, S. S., Stesin, V. V., Shelyagin, V. D., Yurchenko, N. N. and Markov, A. V.: Welding Equipment for Space Applications, Proceedings from the Conference "Welding in Space and the Construction of Space Vehicles by Welding", New Carrollton, Maryland, 1991, pp. 49-58.

3) Schollhammer, F. R.: Electron Beam Welder for Space, Nat. Symp. Materials for Space Vehicle Use, 6th, Seattle, Wash., Society of Aerospace Material and Process Engineer, 1963, p. 51.

4) Nogi, K., Aoki, Y., Fujii, H. and Nakata, K.: Behavior of Bubbles in Weld under Microgravity, Acta Materialia, 46 (1998), pp. 4405-4416.

5) Johnsen, R.: Space Welding Experiment Postponed Indefinitely, Welding J., 76, 4 (1997), p. 22.

6) 吹田義一, 佃 芳行, 高木 隆, 黄地尚義, 増渕興一 : 宇宙空間 での GTA 溶接に関する研究 (第 1 報)，溶接学会論文集，11 (1993), pp. 423-427.

7）吹田義一, 大原将広, 十川弘樹, 松下和憲, 正箱信一郎, 寺嶋 昇, 佃 芳行, 増渕興一, 山内庄司 : 航空機を使用した模擬宇宙 環境での宇宙 GHTA 溶接法によるアルミニウム管の溶接実験， 溶接学会論文集 , 25 (2007), pp. 494-500.

8) 吉田和宏, 西川宏, 黄地尚義, 吹田義一, 増㴊興一: Hollow Cathode Arc 溶接現象に関する基礎的研究, 溶接学会論文集, 20 (2002), pp. 47-52.

9) 正箱信一郎, 太田雅司, 黄地尚義 : Hollow Cathode Arcにおけ 
るアーク柱の特性, 溶接学会論文集 , 23 (2005), pp. 270-275.

10) Kaukler, W. F. and Workman, G. L.: Laser Welding in Space, Proceedings from the Conference "Welding in Space and the Construction of Space Vehicles by Welding", New Carrollton, Maryland, 1991, pp. 318-334.

11）吹田義一, 黑川哲平, 正箱信一郎, 佐藤順子, 莨谷英司, 藤澤正 一郎, 今川吉郎 : 宇宙 LD 溶接法の提案 , レーザ加工学会誌 , 9 (2002), pp. 29-33.

12）吹田義一, 莨谷英司, 杉山智志, 寺嶋 昇, 佃 芳行, 藤澤正一 郎, 今川吉郎: 宇宙空間での宇宙構造物の建造・修理を対象にした 宇宙レーザ溶接法の開発，日本航空宇宙学会論文集，52 (2004), pp. $45-50$.

13) 吹田義一, 田辺心有, 寺嶋 昇, 佃 芳行, 今川吉郎 : 宇宙半 導体レーザ溶接技法による各種環境圧力でのステンレス鋼の溶接 現象，日本航空宇宙学会論文集，53 (2005), pp. 426-430.

14) 山科俊郎, 広畑優子 : 真空工学, 共立出版, 東京, 1991, p. 34, (2.56) 式 .

15) 山科俊郎, 広畑優子 : 真空工学, 共立出版, 東京, 1991, p. 36, 図 2.11 .

16) 山科俊郎，広畑優子：真空工学，共立出版，東京，1991, p. 63, (2.107) 式 .

\section{付 録}

付録 1 真空チャンバ内圧力 $1.7 \times 10^{-3} \mathrm{~Pa}$, 温度 $20^{\circ} \mathrm{C}$ での供試材 SUS304 ステンレス鋼の主成分である鉄気体 分子 (原子直径 $2.7 \times 10^{-10} \mathrm{~m}$ ) の平均自由行程 ${ }^{14)} \lambda_{\mathrm{Fe}}=$ $3.1 \times 10^{-24} T / d^{2} P(T:$ 温度 $(\mathrm{K}), d:$ 気体分子直径 $(\mathrm{m})$, $P$ : 圧力 $(\mathrm{Pa}))$ を概算すると約 $7.33 \mathrm{~m}$ になる . 真空チャン バ直径 $0.6 \mathrm{~m}$ を代表寸法 $D$ として, クヌーセン数 $\lambda_{\mathrm{Fe}} / D$ を求めると $\lambda_{\mathrm{Fe}} / D=7.33 / 0.6=12.2>0.3$ となる. した がって，鉄気体分子の流れは分子流として扱える．この場 合, 溶融池から最短距離で $0.03 \mathrm{~m}$ 離れた石英板に鉄気体分 子か椡達する確率 ${ }^{15)} P_{\mathrm{D}}$ を推算すると $P_{\mathrm{D}}=0.996$ になり， ノズルに侵入したほとんどの鉄気体分子が石英板に到達す ると推察できる . 厳密には, 鉄気体分子同士の衝突以外に 残留空気の窒素分子, 酸素分子などとの衝突も考慮する必 要があるが, 弚れらの分子直径は極端な差がなく $10^{-10} \mathrm{~m}$ オーダーであるから鉄気体分子同士だけの衝突による平均
自由行程に注目しても概略の平均自由行程が概算できる． 付録 2 オリフィスで仕切られた 2 室 A, B があり， A 室のオリフィスの反対側から一定流量のガスが A 室に供 給され, B 室のオリフィスの反対側から真空ポンプで排気 され, オリフィス (ノズル口) から B 室にガスか噴出して いるモデルを考える .このモデルの $\mathrm{A}$ 室の圧力 $P_{\mathrm{A}}$ は式 $P_{\mathrm{A}}=Q / C+P_{\mathrm{B}}\left(P_{\mathrm{A}}: \mathrm{A}\right.$ 室の圧力 $(\mathrm{Pa}), P_{\mathrm{B}}: \mathrm{B}$ 室の圧力 $(\mathrm{Pa}), Q:$ ガス流量 $\left(\mathrm{Pa} \cdot \mathrm{m}^{3} / \mathrm{s}\right), C:$ オリフィスのコンダク タンス $\left.\left(\mathrm{m}^{3} / \mathrm{s}\right)\right)$ で表示できる .コンダクタンス $C$ はノズ ル口面積, 気体定数, 分子量, 温度で決まる ${ }^{16)}$. A 室の圧 力 $P_{\mathrm{A}}$ をノズル内圧力 $P_{\mathrm{N}}, \mathrm{B}$ 室の圧力 $P_{\mathrm{B}}$ を測定した真空 チャンバ内の圧力として 3.2 節の実験条件のノズル内圧力 $P_{\mathrm{N}}$ の推算を試みる .ノズルにシールドガス $\mathrm{Ne}, \mathrm{Ar}, \mathrm{Kr}$ を流量 $0.17 \mathrm{ml} / \mathrm{s}$ で供給し, ノズル口径 $8 \mathrm{~mm}$ から真空チャ ンバ内に噴出させた場合のノズル内圧力 $P_{\mathrm{N}}$ は, 弚れ光れ $2.47,3.47,5.0 \mathrm{~Pa}$ になる . 兴れらの圧力における各気体分 子の平均自由行程は，光れ光れ $4.94 \times 10^{-3}, 1.98 \times 10^{-3}$, $1.05 \times 10^{-3} \mathrm{~m}$ になる (付録 1 ) . これらの各気体分子の中 を鉄気体分子が溶融池から $0.03 \mathrm{~m}$ 離れた石英板に到達す る確率 (鉄気体分子と気体分子は同じ大きさと仮定して) を $\mathrm{Ne}, \mathrm{Ar}, \mathrm{Kr}$ について求めると, 光れ光れ $2.3 \times 10^{-3}$, $2.62 \times 10^{-7}, 3.90 \times 10^{-13}$ となる . 3.1 節のシールドガス を用いない場合に比べて, 鉄気体分子の石英板に到達する 確率は著しく小さくなる．また，同じガス流量では分子量 の大きいガスほど鉄気体分子が石英板に到達する確率が低 くなる．これらの推算結果は, 第 2 表の実験結果と同じ傾 向を示している.

付録 $3 \mathrm{Ar} 16.9 \mathrm{~Pa}$ での $\mathrm{Ar}$ 気体分子の平均自由行程 は $4.06 \times 10^{-4} \mathrm{~m}$ になる . 兴の Ar 中を溶融池から $0.03 \mathrm{~m}$ 離れた石英板に鉄気体分子が到達する確率を推算すると $8.11 \times 10^{-33}$ になる . 